\title{
Local Scale Prioritisation of Green Infrastructure for Enhancing Biodiversity in Peri-Urban Agroecosystems: A Multi-Step Process Applied in the Metropolitan City of Rome (Italy)
}

\author{
Giulia Capotorti ${ }^{1}$, Vera De Lazzari ${ }^{1}$ and Marta Alós Ortí ${ }^{2, *}$ \\ 1 Department of Environmental Biology, Sapienza University of Rome, Piazzale Aldo Moro 5, 00185 Roma, \\ Italy; giulia.capotorti@uniroma1.it (G.C.); delazzari.1413956@studenti.uniroma1.it (V.D.L.) \\ 2 Chair of Biodiversity and Nature Tourism, Estonian University of Life Sciences, Kreutzwaldi 5, \\ 51006 Tartu, Estonia \\ * Correspondence: martaalosorti@gmail.com
}

Received: 5 May 2019; Accepted: 11 June 2019; Published: 16 June 2019

\begin{abstract}
Urban-rural interfaces represent complex systems that require complex solutions for sustainable development and resilience against pollution, habitat fragmentation, biodiversity loss and impaired flux of ecosystem services (ES). Green infrastructure (GI) is increasingly recognised as an effective tool for addressing such a complexity, but needs priority setting to maximise benefits and minimise drawbacks of implementation. Therefore, a prioritisation approach focused on biodiversity and ES in peri-urban areas is required. In the present work, a systematic and hierarchical framework is proposed for setting priority GI objectives, location and actions aimed at enhancing local biodiversity, ES flux and farming sustainability in urban peripheries. By means of a case study in the Metropolitan City of Rome, the framework allowed identification of the main demand for ES and biodiversity; the most suitable location for GI implementation; and the best cost-effective actions. The GI implementation showed an improvement in terms of wooded hedgerow density, an increase regarding the ecological connectivity of riparian ecosystems, and an increment of agroecosystems designated to enhance the ecological network and wildlife support. Finally, the prioritisation framework contributes to fostering environmental benefits while complying with regulations and management practices from the regional to the farm/field decision level.
\end{abstract}

Keywords: urban-rural interface; natural biodiversity in agroecosystems; ecosystem condition; ecological connectivity; hedgerows; river corridors

\section{Introduction}

Exploitation of land resources for human needs, such as soil consumption for urban development and intensive agriculture, is growing worldwide with rising pressures on ecosystems and their services $[1,2]$.

Urban-rural interfaces represent complex systems due to contrasting land use/land cover dynamics, especially residence sprawl vs. maintenance of productive soils and crop abandonment vs. agricultural intensification [3-7]. These dynamics interact with planning and management processes [8-10], resulting in the need for complex solutions aimed at making peri-urban areas sustainable and resilient with respect to pollutant generation and dispersion, habitat fragmentation and biodiversity loss [11-13].

The deployment of green infrastructure (GI), a strategic initiative in Europe for reducing the loss of biodiversity and enable ecosystems to deliver their services to people and nature [14], is increasingly recognised as an effective tool for addressing such a complexity [15-17]. Manifold interpretations 
to the GI concept are available in the international academic literature, which alternatively focus on recreation, public health, stormwater management, climate change adaptation, habitat fragmentation or on different combinations of these targets [18]. Nevertheless, at the EU level GI is officially defined as a "strategically planned network of high quality natural and semi-natural areas with other environmental features, which is designed and managed to deliver a wide range of ecosystem services and protect biodiversity in both rural and urban settings" [14].

On the basis of the above-mentioned definition, GI represents a multifunctional tool that allows multiple challenges to be concurrently faced $[19,20]$. These include different targets of the EU Biodiversity Strategy for 2020 (especially Target 2 on ecosystem maintenance and restoration, Target 3 on sustainable agriculture and forests, and Target 4 on biological invasion control) as well as definite aspects of the UN Sustainable Development Goals (SDG) for 2030 (e.g., the promotion of sustainable agricultural production for SDG 2, promotion of green and resilient cities for SDG 11, and climate change adaptation and mitigation planning for SDG 13) [21-24].

Multifunctional GI involving urban peripheries may favour the local flow of ecosystem services (ES) between interwoven providing and benefitting areas $[25,26]$. Since good ecosystem conditions are the prerequisite for sustaining this flow [27], restoration efforts are particularly required in peri-urban natural and semi-natural ecosystems that are affected by heavy pressures and impacts [28]. Similarly, conservation actions are recommended when ecosystem conditions are suitable for maintaining this flux of ES.

In order to maximise benefits and minimise trade-offs by means of GI, a priority setting for restoration and conservation actions focused on biodiversity and ES is still needed [29,30]. Indeed, the EU Biodiversity Strategy endorses prioritisation as a strategic approach for increasing the effectiveness of these actions [22]. Consequently, some methods aimed at identifying priority features for GI implementation have recently emerged [31,32], which have been alternatively focused on ES (i.e., what a GI should mainly provide), locations (i.e., where a GI could be best deployed) and actions (i.e., how a GI may improve ecosystem conditions as well as increase the capacity to deliver ES) [27,33,34]. Notwithstanding prioritisation processes in the context of GI deployment have been applied in several urban areas [35-38], common paradigms to define priorities in rural and peri-urban areas are still lacking and available experimental evidences are mainly limited to coarse scale investigations $[39,40]$ and/or adoption of planning procedures that overlook explicit priority-setting [41]. Therefore, on the basis of a case study carried out in the Metropolitan City of Rome, the paper is aimed at outlining prioritisation phases that are suitable for planning GI in peri-urban agricultural landscapes affected by severe urban expansion. The study highlights the key role of prioritisation of objectives, locations and actions, at multiple scales and for different decision levels, to simultaneously approach biodiversity and ES concerns.

\section{Materials and Methods}

\subsection{Study Area}

The Metropolitan City of Rome embraces the Municipality of Rome, capital of Italy, and 120 minor municipalities. It is on the central-western side of the Italian peninsula and belongs to the Roman Area Ecoregion, which is characterised by climatic and physiographic features supporting an agricultural exploitation of land since ancient ages [42,43]. The historical agricultural matrix has been increasingly threatened by urban fabric expansion, causing shrinking, fragmentation and degradation of valuable agroecosystems [44,45]. These processes are especially marked in the eastern part of the metropolitan area [46].

For the present study, the peri-urban sector of the eastern metropolitan area, named Ancient Agro Romano, has been considered. The focus is on the urban-rural interface across the municipalities of Rome (with a population density of 2018 inhabitants $/ \mathrm{km}^{2}$ ), Guidonia Montecelio (1055 inhabitants $/ \mathrm{km}^{2}$ ) and Tivoli (774 inhabitants $/ \mathrm{km}^{2}$ ) [47] (Figure 1), which is characterised by a 
transitional sub-Mediterranean bioclimate. The typical geomorphology of the wider 'Agro Romano', an extensive undulating volcanic plain dissected by the drainage network, is specifically characterised in the study sector by an ignimbrite plateau, together with travertine outcrops, clayey hills and lava flows, crossed by the alluvial plain of the Aniene River, one of the main tributaries of the Tiber River [42].

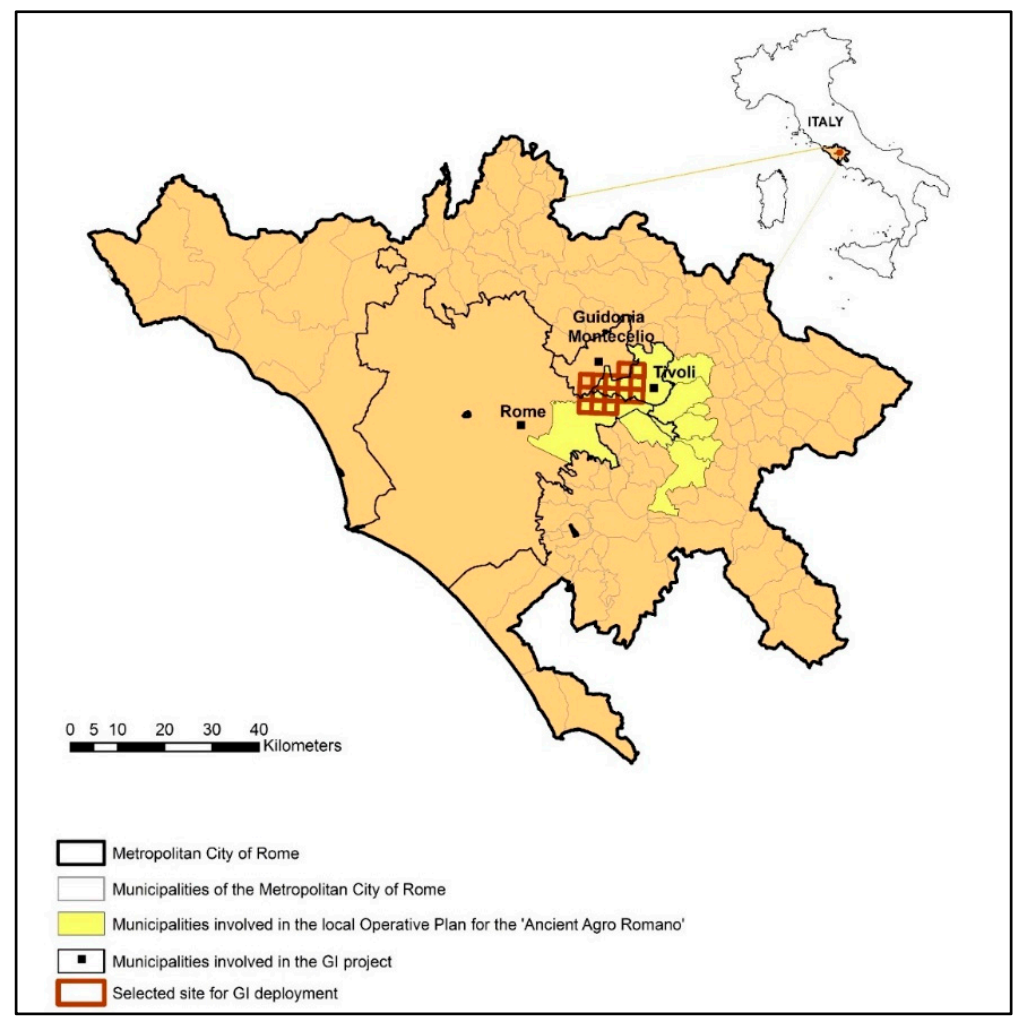

Figure 1. Geographical location of the study area and spatial arrangement of the administrative units.

\subsection{Overall GI Design Process}

For the GI design, the multi-step planning process applied in an urban sector of the Municipality of Rome [48] was resumed and properly customised to the peri-urban agricultural setting at issue. Therefore, for each of the steps 'Selection of the objective', 'Definition of project site', and 'Definition of GI components/actions' (Figure 2a), specific prioritisation criteria (Figure 2b) that operate at different scales and decision levels (Figure 2c) were defined:

- Step A-Definition of priority GI objectives, considering the synergic demands for biodiversity restoration/conservation and ES provision at the landscape scale (metropolitan/regional decision level);

- $\quad$ Step B-Identification of a priority location for GI deployment, according to the spatial overlay of critical issues for both biodiversity and ES at the countryside scale (municipal/sub-municipal decision level);

- Step C-Definition of priority restoration and conservation actions, according to ecosystem extent and condition at the site scale (farm/field decision level).

At the end of the process, a recognition of the environmental benefits potentially provided by GI interventions was performed. 


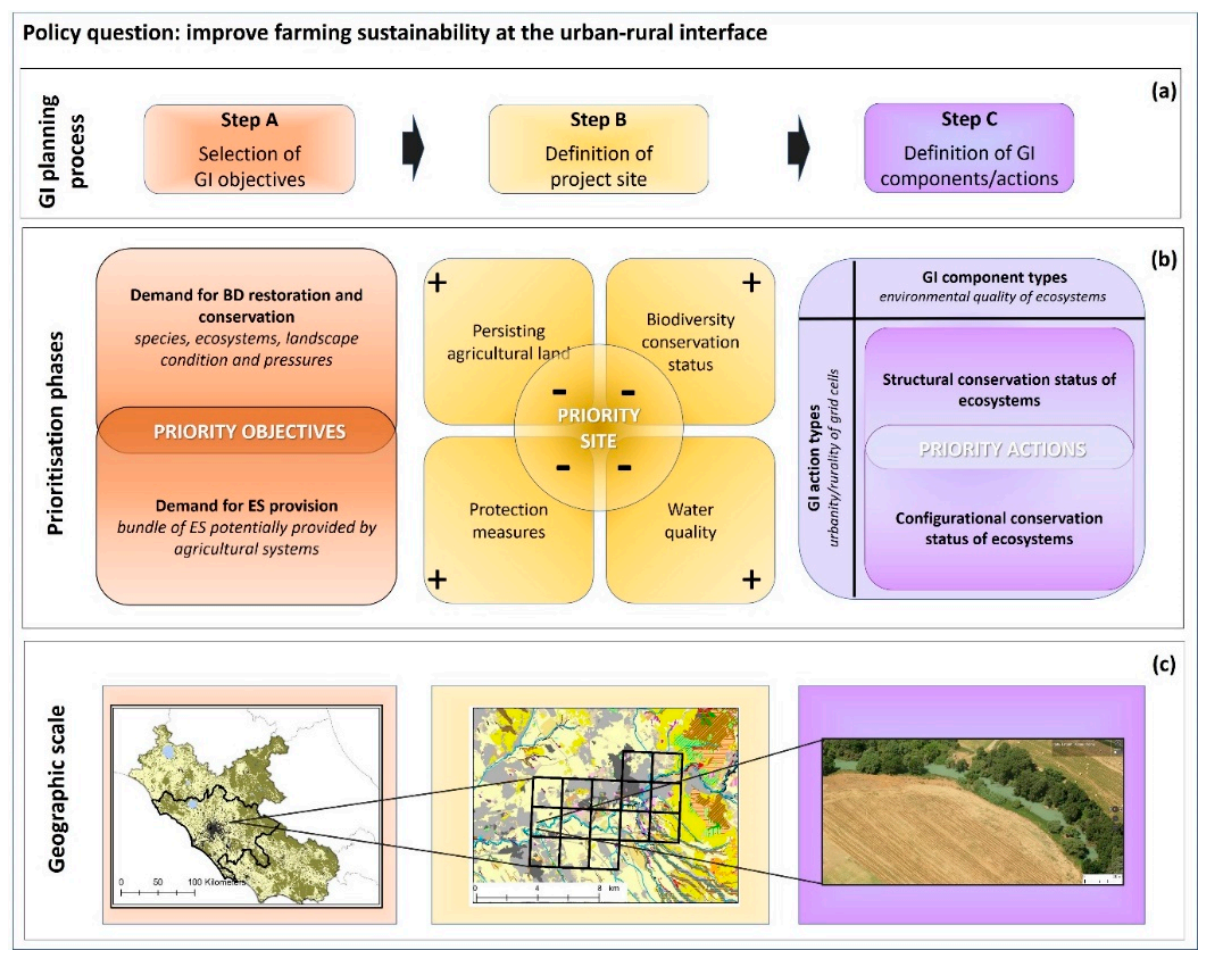

Figure 2. Multi-step green infrastructure (GI) design process for improving farming sustainability at the urban-rural interface (policy question in the outer frame). For each of the planning steps (a), a specific prioritisation phase (b) that operates at a different scale (c) is defined. Abbreviations: $\mathrm{BD}=$ biodiversity; ES = ecosystem services; $+=$ high; $-=$ low.

\subsubsection{Step A-Prioritisation of GI Objectives}

In the broader framework of sustainable agricultural land-use, the prioritisation of GI objectives was based on the analysis of impacts that urban expansion and agricultural intensification cause on natural biodiversity and ES capacity in the considered peri-urban sector (Figure 2, step A).

Priority demands for biodiversity restoration and conservation were derived from indicators on ecosystem condition and pressures, as reported in available scientific literature and technical reports of regional and metropolitan plans. In particular, these data include: (i) the information joined to the Land Ecological Network of the General Provincial Territorial Plan and concerning the occurrence and distribution of species and vegetation communities, as well as the conservation status of ecological land units [49-52]; (ii) the regional maps and descriptive documents of protected areas and Natura2000 sites (according to the EU Habitats Directive 92/43/EEC) [53]; (iii) different land use/land cover maps and the accompanying assessments of change trends $[52,54,55]$ and (iv) the information joined to the Regional Water Conservation Plan [56] and concerning the quality of water bodies and river basins (according to the Water Framework Directive 2000/60/EC).

To infer the priority demands of ES, the bundle of services (i.e., the set of ES linked to a given ecosystem and repeatedly appearing together across time or space; $[57,58])$ provided by agricultural systems was explored [59-62]. Apart from provisioning ES, which strictly depend on human management (e.g., food production) and are weakly related to the main interest of the project into natural biodiversity restoration and conservation, regulating and cultural agroecosystem services that are relevant to the study area were identified by a review of the available scientific and grey literature.

\subsubsection{Step B-Prioritisation of GI Location}

A priority site for GI deployment (Figure 2, step B) was selected by means of spatial co-occurrence of critical features arising from the previous step. Namely, it was driven by: (i) setting in an urban-rural interface, with still prevalent agricultural land use but with marked recent urbanisation trends; (ii) low 
conservation status of the ecological land units, together with low naturalness of the vegetation cover and low species richness; (iii) presence of a main water course, in a poor ecological status and facing very high pressures from pollution sources; (iv) scarce coverage of protected areas (i.e., natural or agricultural parks, Natura2000 sites, core areas of the Land Ecological Network).

The grid of $2 \mathrm{~km} \times 2 \mathrm{~km}$ cells, which has been employed for the species distribution maps accompanying the General Provincial Territorial Plan (i.e., vascular plant, mammal, bird, amphibian and reptile species richness and conservation concern) [52], was adopted for delineating the site. On the one hand, the adoption of grid cells allowed the information about species to be properly combined in the site selection process and, on the other hand, it facilitated the next prioritisation phase to be performed (Figure 2, step C). Actually, multiple ecosystems and other land use/land cover types occur in each cell and are arranged in different ways. Therefore, these occurrences and arrangements were deemed suitable for measuring the degree of urbanisation across the study area as well as for assessing ecosystem condition within each cell of the urban-rural gradient $[63,64]$.

\subsubsection{Step C—Prioritisation of GI Restoration and Conservation Actions}

Priority restoration and conservation actions (Figure 2, step C) were set on the basis of fine-grained mapping and assessment of ecosystems in the selected site.

For this purpose, a land use/land cover map of the selected 15 grid cells was manually created by photo-interpretation of aerial imagery. ArcGIS BaseMap from 2015 with a resolution of $0.5 \mathrm{~m}$ was used and photo-interpretation was conducted at a scale of 1:2000. The adopted minimum mapping unit for areal elements was 0.5 ha and the adopted minimum width for stretched elements was of $5 \mathrm{~m}$. Such a minimum width allows the spatial continuity of important GI components, that is river courses and riparian vegetation, to be always represented in the map.

Land use/land cover types were classified by combining the thematic information of the Lazio Region land use map at 1:10,000 scale [65], which extends the EU Corine Land-Cover legend up to the IV/V hierarchical level, with the thematic information of the vegetation cover Map of the Province of Rome at 1:25,000 scale [51]. Such an integration allowed the identification of the different ecosystem types occurring in the study area [66].

In keeping with the EU 'Mapping and Assessment of Ecosystem and their Services' (MAES) approach [67], cropland systems have been considered as agroecosystems, i.e., "managed ecosystems supporting semi-natural vegetation along food production". Croplands may include cultivated and domestic habitats, including associated landscape elements, as well as significant coverage of natural vegetation when arranged in agricultural mosaics. Accordingly, linear semi-natural features, which play an important role for biodiversity and ES in agricultural lands [68,69], were mapped in a separate layer.

The thematic accuracy of the resulting maps was improved by field validation in accessible sites and by open source geovisualisation tools, i.e., Google Street View and Bing Maps, for inaccessible sites.

In line with the main policy question beyond the study, GI components were selected among agricultural surfaces and residual vegetation communities as ecosystems that actually or potentially host natural biodiversity and have the capacity to provide the ES identified by means of the first planning step.

Therefore, restoration/conservation actions were prioritised after the assessment of the respective ecosystem conservation status of such GI components. Criteria for the assessment were customised from those adopted for the implementation of the MAES process at the national level [70] and included:

1. The environmental quality of different ecosystem types (determined according to the degree of soil sealing, the impact of agricultural practices on ecological resources and processes and the distance from potential natural vegetation) [71,72];

2. The degree of urbanity/rurality of grid cells (determined by the relative extent of artificial, agricultural and natural cover types and the contacts between them); 
3. The conservation status in structural terms of ecosystem patches occurring in each grid cell (determined according to patch extent and presence/absence of linear semi-natural elements);

4. The conservation status in terms of spatial configuration of ecosystem types in each grid cell (determined according to measures of ecosystem isolation and quality of the spatial contacts).

Digital maps were created and analysed by using ESRI ArcMap 10.1, while landscape metrics were calculated using the spatial pattern analysis software FRAGSTATS 4 [73]. Namely, the Euclidean Nearest-Neighbour Distance (ENN) between semi-natural ecosystem patches was measured as a proxy for isolation, while contacts between different land use/land cover classes were analysed as a proxy for both land use intensity (contacts between agricultural and artificial surfaces) and riparian corridor integrity (contacts between water course and riparian forests).

Additionally, a list of woody species to be primarily adopted for restoration actions was compiled. In order to effectively respond to the biodiversity objective of the GI, the list included trees and shrubs that are native of the Roman Area Ecoregional Subsection and are coherent with the potential natural vegetation of the site [43,74-76]. Regarding the enhancement of ecological connectivity, plant dispersal capacity and positive relationships with faunal biodiversity were taken into account. Thus, species with short-distance dispersal potential and/or high capacity to provide food and shelter for wild animals were considered relevant [48,77-79]. The suitability to support wild pollinators was derived from regional lists of melliferous flora, which display plant species with a significant nectar, pollen or honeydew production capacity [80,81].

\subsubsection{Recognition of Expected Benefits}

The recognition of environmental, social and economic benefits represents the final step for effectively promoting GI implementation.

In keeping with the primary focus of the present research, the assessed benefits were limited to the environmental sphere and, in particular, to the improved density of wooded hedgerows within the agricultural matrix, the increased ecological connectivity of the riparian ecosystems, and the extent of agroecosystems designated to enhance the ecological network and to support wildlife. These biophysical values were estimated by comparing the initial and the simulated post-intervention situation.

\section{Results}

\subsection{Priority GI Objectives in the Ancient Agro Romano Metropolitan Sector}

The available scientific literature and technical reports highlight that land take processes have markedly shrunk and fragmented natural ecosystems in the analysed peri-urban agricultural landscape. Therefore, according to the recognised critical features in terms of ecosystem condition and pressures (Table 1), the following priority objectives for biodiversity restoration/conservation in the Ancient Agro Romano were derived from the combination of recommendations provided by the metropolitan, regional and river basin authorities:

- Enhancement of ecological connectivity, especially in the agricultural matrix and along river corridors, wherever the richness of species of conservation concern and landscape conservation status are low and the ecological status of water courses is poor [42,52];

- Restoration of vulnerable and biogeographically representative communities, especially mixed woods with Quercus cerris and Q. virgiliana/Q. pubescens, Quercus cerris woods with Carpinus orientalis, and riparian vegetation mosaic wherever natural and semi-natural vegetation is heavily shrunk and fragmented [52];

- Forest planting and plantation of trees and shrubs throughout the agricultural matrix especially in land units with low landscape conservation status, such as alluvial plains and lava flows, and wherever the pressure on the Aniene River course from diffuse sources is very high [50,52]; 
- Improved balance between quarry activities and biodiversity conservation in the travertine outcrop land unit that shows a very low conservation status [52];

- Enhancement of environmental protection tools wherever the number and extent of protected sites are very limited, i.e., realisation of the Ancient Agro Romano Metropolitan Park and of the Provincial Park of the River Aniene corridor, creation of buffer zones around the Natura2000 sites, and strict preservation of the ecological corridors of the Land Ecological Network [52,56];

- Promotion of land-saving urban forms and conservation of the traditional agricultural landscape wherever the incidence of urban sprawl is high [46,54,55,82];

- Enhancement of self-healing capacity and banks stabilisation of the river courses by means of restored riparian vegetation [56];

- $\quad$ Restoration of the entire floodplain by means of morphology and vegetation requalification [56].

Table 1. Critical features that underpinned the selection of priority GI objectives for biodiversity restoration/conservation in the Ancient Agro Romano metropolitan sector. Type of indicators: $\mathrm{C}=$ Condition; $\mathrm{P}=$ Pressure. Territorial level: $\mathrm{M}=$ Metropolitan City; $\mathrm{R}=$ Region.

\begin{tabular}{|c|c|c|c|c|}
\hline Indicator & Type & $\begin{array}{l}\text { Territorial } \\
\text { Level }\end{array}$ & Description & $\begin{array}{c}\text { Critical } \\
\text { Conditions and Pressures } \\
\text { Occurring in the Ancient Agro Romano }\end{array}$ \\
\hline $\begin{array}{l}\text { Species occurrence and } \\
\text { distribution }\end{array}$ & $\mathrm{C}$ & M & $\begin{array}{l}\text { Number of species per } 2 \mathrm{~km} \times 2 \mathrm{~km} \text { grid } \\
\text { cells in the Ancient Agro Romano ( } 129 \text { out } \\
\text { of the } 1560 \text { cells of the Metropolitan City) }\end{array}$ & $\begin{array}{l}\text { Prevailing very low richness and uneven } \\
\text { distribution of species of conservation } \\
\text { concern } \\
\text { (52\% of cells without records; } 32 \% \text { of cells } \\
\text { with less than } 5 \text { species; } 8 \% \text { of cells with } \\
6-10 \text { species; } 5 \% \text { of cells with } 11-20 \text { species; } \\
3 \% \text { of cells with more than } 20 \text { species) }\end{array}$ \\
\hline $\begin{array}{l}\text { Natural and } \\
\text { semi-natural } \\
\text { vegetation occurrence } \\
\text { and distribution }\end{array}$ & $\mathrm{C}$ & M & $\begin{array}{l}\text { Number, extent and isolation of } \\
\text { autochthonous forest patches in the } \\
\text { peri-urban area }\end{array}$ & $\begin{array}{l}\text { Persistence of small and isolated fragments } \\
\text { of autochthonous forests } \\
\text { ( } 235 \text { patches with a mean area of } 7 \text { ha and a } \\
\text { mean distance from the nearest } \\
\text { neighbourhood of } 338 \mathrm{~m} \text { ) }\end{array}$ \\
\hline $\begin{array}{l}\text { Landscape } \\
\text { conservation status }\end{array}$ & $\mathrm{C}$ & M & $\begin{array}{l}\text { Index of Landscape Conservation (ILC) } \\
\text { measured for distinct ecological land units } \\
\text { in the peri-urban area (the index varies } \\
\text { between } 0.0-\text { high level of artificialisation } \\
\text { and 1.0-high level of naturalness) }\end{array}$ & $\begin{array}{l}\text { Low conservation status of occurring } \\
\text { ecological land units } \\
(0.2<\text { ILC } \leq 0.4 \text { for alluvial plains, } \\
\text { travertine outcrops, detritic fans and } \\
\text { polygenic conglomerates, clayey hills, } \\
\text { volcanic hills, lava flows) }\end{array}$ \\
\hline $\begin{array}{l}\text { Protected areas; } \\
\text { Natura2000 sites; main } \\
\text { components of the } \\
\text { Land Ecological } \\
\text { Network (LEN) }\end{array}$ & $\mathrm{C}$ & $\mathrm{R}$ & $\begin{array}{l}\text { Number and extent of protected sites } \\
\text { within the Ancient Agro Romano }\end{array}$ & $\begin{array}{l}\text { Lack of protected areas; } \\
2 \text { Natura2000 sites/core areas of the LEN } \\
\text { ( } 931 \text { ha); } \\
\text { Lack of buffer zones of the LEN }\end{array}$ \\
\hline Quality of water bodies & $\mathrm{C}$ & $\mathrm{R}$ & $\begin{array}{l}\text { Combined assessment of the biological and } \\
\text { physical-chemical status of the Aniene } \\
\text { water course in the peri-urban area }\end{array}$ & $\begin{array}{l}\text { Ecological status varying from 'moderate' } \\
\text { to 'poor' }\end{array}$ \\
\hline $\begin{array}{l}\text { Land use/land cover } \\
\text { changes }\end{array}$ & $\mathrm{P}$ & M & $\begin{array}{l}\text { Intensity and typology of changes in the } \\
\text { peri-urban area in different time-spans } \\
\text { (1954-2001; 1960-2008) }\end{array}$ & High incidence of urban sprawl \\
\hline $\begin{array}{l}\text { Environmental quality } \\
\text { of the river basins }\end{array}$ & $\mathrm{P}$ & $\mathrm{R}$ & $\begin{array}{l}\text { Load of pollutants (organic materials and } \\
\text { nitrogen) from agriculture, industry, } \\
\text { population in the Aniene River Basin }\end{array}$ & $\begin{array}{l}\text { Very high pressure on the water courses } \\
\text { from diffuse sources }\end{array}$ \\
\hline
\end{tabular}

Concurrently, the bundle of regulating and cultural ES potentially provided by agroecosystems, which was recognised of local relevance and should be particularly enhanced by the GI deployment, includes: erosion control [83]; flood protection [52,84]; pollination support [85]; nursery populations and habitats maintenance [86]; soil fertility regulation [87]; water quality regulation [56]; experiential and physical use of plants, animals and landscape [87]; landscape assets protection [52,87]; existence and bequest preservation [42].

\subsection{Priority Location for GI Deployment at the Urban-Rural Interface}

The selected location for GI deployment consists of 15 grid cells of $2 \mathrm{~km} \times 2 \mathrm{~km}$ each, along the Aniene River, for a total area of 6000 ha (Figure 1). It is located at the interface between the urban area of Rome and the surrounding traditional agricultural landscape of Agro Romano, encompassing 
different stages of the urban-to-rural gradient. Current artificial surfaces result from typical dynamics of the municipalities close to the main city, which underwent a marked increase of relatively compact land take between 1961 and 1981 and a successive sprawling phase with dispersed new settlements in more recent periods.

All the critical features listed in Table 1 occur in the site. Species of conservation concern per cell vary between 0 (in 7 cells) and 3 (in 1 cell), with respect to the highest value of 36 species per cell occurring in the immediately surrounding natural area. The landscape conservation status of all occurring ecological land units, i.e., alluvial plains, pyroclastic hills, clayey hills, travertine outcrop plains and lava flows, is 'low'. Natural vegetation cover is even more reduced and fragmented with respect to the overall Ancient Agro Romano, where forest cover is yet limited to $6 \%$ of the total surface. Moving towards the city of Rome, the ecological status of the River Aniene varies from 'moderate' to 'poor' and pressures by Nitrogen pollution in the river basin vary from medium (4.8-7.8 t/year $\left./ \mathrm{km}^{2}\right)$ to very high levels (14.2-20.6 t/year $\left./ \mathrm{km}^{2}\right)$.

Being the institution of an 'Agricultural Park of Ancient Agro Romano' still a proposal, the only protected area, as well as the unique core area of the metropolitan Land Ecological Network, is the Natura2000 site of 'Travertine and Acque Albule'. It preserves few rare and vulnerable plant species (e.g., Chaenorhinum rubrifolium, Clypeola jontlaspi, Agrostis monteluccii) and two EU priority habitats (6220-Pseudo-steppe with grasses and annuals of Thero-Brachypodietea and 6110-Calcareous or basophilic grasslands of Alysso-Sedion albi) [88].

\subsection{Priority GI Restoration and Conservation Actions}

The land use/land cover map of the site (Figure 3) displays an agricultural landscape matrix (about 3180 ha, $53 \%$ of the total surface), which is mainly composed of croplands belonging to the low environmental quality class (1802 ha of non-irrigated arable land and 102 ha of permanently irrigated land) and, secondarily, to the medium-low environmental quality class (320 ha of permanent crops). Artificial areas, all belonging to the very low environmental quality class, are the second prevalent cover type (about 2200 ha, $37 \%$ of the total surface) and are mainly composed of discontinuous urban fabric (1081 ha). Natural and semi-natural ecosystems are limited to less than $10 \%$ of the total surface (about $580 \mathrm{ha}$ ) and are mainly composed of 'Transitional woodland scrub' (160 ha, high environmental quality class), 'Quercus cerris woods with Carpinus orientalis' ( 145 ha, very high environmental quality class), 'Deciduous shrublands with Prunus spinosa and Ulmus minor' (115 ha, high environmental quality class) and 'Hygrophilous riparian woodland with Salix alba and Populus sp. pl.' (110 ha, very high environmental quality class).

In general, all permanent crops, heterogeneous agricultural areas and residual natural and semi-natural ecosystems, were designated as GI components to be always preserved for biodiversity conservation and ES provision with any further prioritisation (Figure $4 \mathrm{~b}$ ). Permanent crops and heterogeneous agricultural areas are intrinsically rich in terms of biodiversity and their environmental quality ranges from medium-low to medium-high (Figure 3). Residual natural and semi-natural ecosystems have an environmental quality ranging from medium-high to very high (Figure 3). 

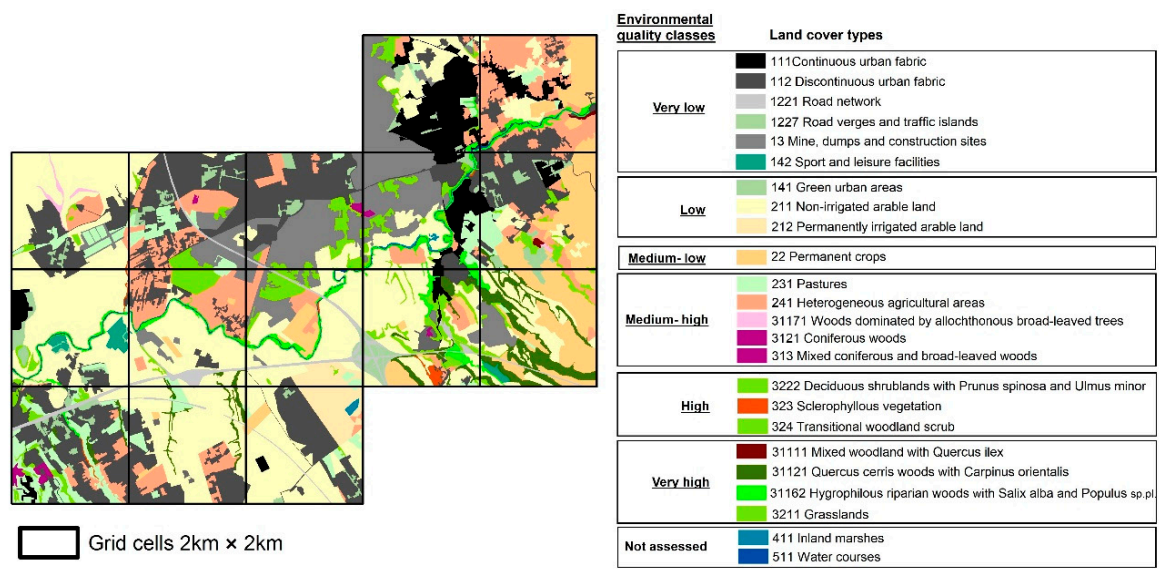

Figure 3. Land use/land cover map of the selected location for GI deployment (reduction of the original map at a scale of 1:2000). The environmental quality classes assigned to the different land use/land cover types are shown in the legend.

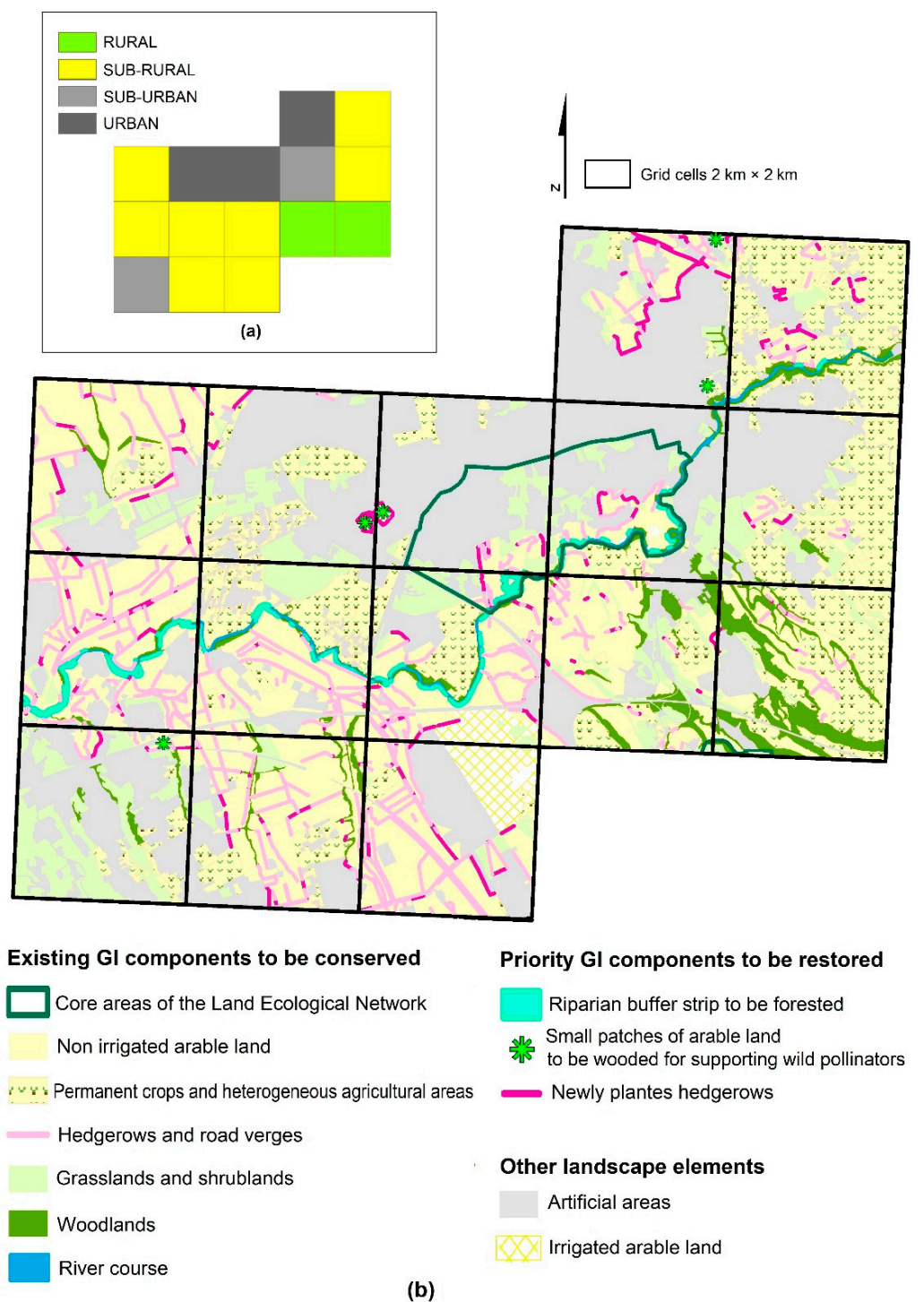

Figure 4. Plan for the deployment of a peri-urban GI in the Ancient Agro Romano: (a) Classification of grid cells according to the degree of urbanity/rurality; (b) Spatial representation of GI components to be conserved or restored with priority. 
Concurrently, patches of non-irrigated arable land, with an assigned low environmental quality (Figure 3), were designated as GI components for placing restoration actions in keeping with the main GI objectives set for the entire Ancient Agro Romano (see sub-Section 3.1) and according to the degree of urbanity/rurality of the grid cells.

As for the latter, the following types were recognised (Figure 4a):

- Rural cells (2 out of 15), which are characterised by an agricultural matrix (ranging from $55 \%$ to $62 \%$ of the cell's surface) with relatively high persistence of (semi-)natural ecosystems (ranging from $24 \%$ to $27 \%$ ) and small amount of shared contacts between agricultural and artificial surfaces (ranging from $9 \%$ to $23 \%$ of the overall contacts of agricultural surfaces);

- Sub-rural cells (8 out of 15), which are characterised by an agricultural matrix (ranging from 53\% to $72 \%$ of the cell's surface) with relatively high coverage of artificial areas (ranging from 19 to $40 \%$ ), from very few to few persisting (semi-) natural ecosystems (ranging from $0.1 \%$ to $13 \%$ ), and large amount of shared contacts between agricultural surfaces and artificial areas (ranging from $42 \%$ to $65 \%$ of the overall contacts of agricultural surfaces);

- Sub-urban cells (2 out of 15), which are characterised by an artificial matrix (ranging from 53\% to $59 \%$ of the cell's surface) with relatively high coverage of agricultural surfaces (ranging from $25 \%$ to $36 \%$ ), few persisting (semi-) natural ecosystems (ranging from $11 \%$ to $13 \%$ ), and small to medium share of contacts between agricultural surfaces and artificial areas (ranging from $16 \%$ to $40 \%$ of the overall contacts of agricultural surfaces);

- Urban cells (3 out of 15), which are characterised by an artificial matrix (ranging from $60 \%$ to $80 \%$ of the cell's surface) with relatively low coverage of agricultural surfaces (ranging from $12 \%$ to $32 \%$ ), very few persisting (semi-) natural ecosystems (ranging from $5 \%$ to $9 \%$ ), and very large share of contacts between agricultural surfaces and artificial areas (ranging from $74 \%$ to $85 \%$ of the overall contacts of agricultural surfaces).

For each type of cell, the following specific restoration actions were established (Figure $4 \mathrm{~b}$ ) and pertaining priority was assigned with respect to the structural and configurational conditions of ecosystems:

- In rural cells the improvement of landscape elements density for enhancing the ecological connectivity was set as the main restoration action. In this case, restoration priority was given to the densification of woody landscape elements within extensive patches of arable land that are placed between the most distant (semi-)natural ecosystems;

- In sub-rural cells main restoration actions and pertaining priority were set as (i) the densification of woody landscape elements within arable land, especially for extensive patches placed between isolated (semi-)natural ecosystems (in the 4 cells with high ENN values, ranging from 85 to $1614 \mathrm{~m}$ ), and (ii) restoration of the riparian vegetation wherever the river course adjoined some agricultural surface;

- In sub-urban cells main restoration actions and pertaining priority were set as (i) the densification of woody landscape elements within arable land, especially for the agroecosystem patches that are more extensive and/or may improve the ecological connections between the Natura2000 site and the surrounding landscape, and (ii) restoration of habitats that are suitable for supporting wild pollinators in small residual and no longer cultivated patches;

- In urban cells main restoration actions and pertaining priority were set as i) the densification of woody landscape elements within extensive patches of arable land to connect distant (semi-)natural ecosystems and to reduce contrast with adjoining artificial areas, and ii) restoration of habitats that are suitable for supporting wild pollinators in small residual and no longer cultivated patches.

A selection of the native woody species that can be planted for restoration actions is presented in Table 2. For each species, the coherence with the six potential natural vegetation types occurring in the site and the importance to support plant dispersion are shown. Almost all the species are 
suitable for the support of pollinators and can provide food and/or shelter for wild animals, but their functional relevance is stated only for those reported as 'very important' in the considered literature. Nomenclature of the species follows Anzalone et al. [89].

Table 2. Selection of native trees and shrubs suggested for plantation according to potential natural vegetation types (RIP = riparian forests with Salix alba, Populus sp.pl. and Alnus glutinosa; HYG = meso-hygrophilous forests with Quercus robur and Ulmus minor of the alluvial plains; TRV = mixed oak forests with Quercus pubescens of the travertine outcrops; CLY = deciduous oak forests with Quercus cerris of the clayey hills; PIR = deciduous oak forests with Quercus cerris and Carpinus orientalis of the pyroclastic plateaux; LVF = mixed oak forests with Quercus cerris or $Q$. ilex of the lava flows) and functional relevance (DIS = ecological connectivity/plant dispersal; WLD = ecological connectivity/food and shelter for wild animals; POL = pollinator support).

\begin{tabular}{|c|c|c|c|c|c|c|c|c|c|}
\hline \multirow{2}{*}{$\begin{array}{c}\text { Species } \\
\text { Native Trees }\end{array}$} & \multicolumn{6}{|c|}{ Potential Natural Vegetation } & \multicolumn{3}{|c|}{ Functional Relevance } \\
\hline & RIP & HYG & TRV & CLY & PYR & LVF & DIS & WLD & POL \\
\hline Acer campestre $\mathrm{L}$. & & $X$ & & $\mathrm{x}$ & $x$ & & & & $\sqrt{ }$ \\
\hline Acer monspessulanum $\mathrm{L}$. & & & $x$ & & & $x$ & & & $\sqrt{ }$ \\
\hline Alnus glutinosa (L.) Gaertn. & $\mathrm{x}$ & & & & & & & & $\sqrt{ }$ \\
\hline Carpinus orientalis Mill. & & & $\mathrm{x}$ & $\mathrm{x}$ & $\mathrm{x}$ & & & & $\sqrt{ }$ \\
\hline Celtis australis $\mathrm{L}$. & & & & $x$ & & & & $\sqrt{ }$ & \\
\hline Cercis siliquastrum $\mathrm{L}$. & & & $x$ & & & & & & $\sqrt{ }$ \\
\hline Fraxinus ornus $\mathrm{L}$. & & & & $\mathrm{x}$ & $\mathrm{x}$ & $\mathrm{x}$ & & & $\sqrt{ }$ \\
\hline Fraxinus angustifolia Vahl subsp. oxycarpa & & $\mathrm{x}$ & & & & & & & $\sqrt{ }$ \\
\hline Ostrya carpinifolia Scop. & & & & $\mathrm{x}$ & & & & & $\sqrt{ }$ \\
\hline Populus alba $\mathrm{L}$. & $\mathrm{x}$ & $x$ & & & & & & $\sqrt{ }$ & $\sqrt{ }$ \\
\hline Quercus cerris L. & & & & $\mathrm{X}$ & $\mathrm{x}$ & $\mathrm{x}$ & $\sqrt{ }$ & & $\sqrt{ }$ \\
\hline Quercus ilex L. subsp. ilex & & & $x$ & & & $x$ & $\sqrt{ }$ & & $\sqrt{ }$ \\
\hline Quercus pubescens Willd. subsp. pubescens & & & $\mathrm{x}$ & $\mathrm{x}$ & & $\mathrm{x}$ & $\sqrt{ }$ & & $\sqrt{ }$ \\
\hline Quercus robur L. subsp. robur & & $x$ & & & & & $\sqrt{ }$ & & $\sqrt{ }$ \\
\hline Salix alba L. subsp. alba & $\mathrm{x}$ & & & & & & & & $\sqrt{ }$ \\
\hline Ulmus minor Mill. subsp. minor & & $x$ & & $x$ & $x$ & & & $\sqrt{ }$ & \\
\hline Native shrubs & & & & & & & & & $\sqrt{ }$ \\
\hline Cornus mas $\mathrm{L}$. & & & & $x$ & & $\mathrm{x}$ & & & $\sqrt{ }$ \\
\hline Cornus sanguinea L. subsp. sanguinea & $\mathrm{x}$ & $\mathrm{x}$ & & & $\mathrm{x}$ & & & & $\sqrt{ }$ \\
\hline Crataegus monogyna Jacq. subsp. monogyna & $\mathrm{x}$ & & $\mathrm{x}$ & $\mathrm{x}$ & $\mathrm{x}$ & $\mathrm{x}$ & & $\sqrt{ }$ & $\sqrt{ }$ \\
\hline Cytisus villosus Pourr. & & & & & $\mathrm{x}$ & & $\sqrt{ }$ & $\sqrt{ }$ & \\
\hline Laurus nobilis L. & & & & & $x$ & & & $\sqrt{ }$ & $\sqrt{ }$ \\
\hline Ligustrum vulgare $\mathrm{L}$. & & & & $\mathrm{x}$ & $\mathrm{x}$ & & & & \\
\hline Prunus spinosa L. subsp. spinosa & & & & & $x$ & $\mathrm{X}$ & & $\sqrt{ }$ & $\sqrt{ }$ \\
\hline
\end{tabular}

\subsection{Expected Benefits}

The environmental benefits potentially provided by the above-mentioned actions mainly consist of improved ecosystem quality and environmental resilience and have been quantified as follows.

Farmland biodiversity loss is expected to be counteracted and ecological connectivity is expected to be improved by means of the increased density of woody linear elements, from 48.53 to $62.65 \mathrm{~m} / \mathrm{ha}$, in about 1800 ha of arable land (56\% of the total agricultural surface) within urban, sub-urban and some sub-rural cells.

Quality and functionality of riparian ecosystems are expected to increase in 4 out of the 7 cells crossed by the Aniene River, with restored contacts between the water course and riparian forests along $1191.38 \mathrm{~m}$ of the river banks. For the 3 cells classified as sub-rural, the proportion of these contacts is expected to rise from $88 \%$ to $96 \%$, from $92 \%$ to $95 \%$ and from $98 \%$ to $100 \%$, respectively. For the sub-urban cell, the same proportion is expected to rise from $85 \%$ to $87 \%$. Considering a minimum buffer strip of $15 \mathrm{~m}$ from banks on both sides of the river, as the technical standards of the river basin plan prescribe, this restoration action requires about 1.79 ha, i.e., less than $1 \%$ of the total agricultural surface of the site.

Land Ecological Network performance is expected to be enhanced in 257 ha of arable land ( $8 \%$ of the total agricultural surface), mainly in the rural cells. This will be achieved by preserving/restoring natural stepping stones and improving the ecological connections between the 'Travertine and Acque 
Albule' Natura2000 site and the core area of 'San Vittorino and Vallone di Pontelupo', which is located immediately outside the study area.

Support to wild pollinators is expected to be enhanced by planting suitable woody species in about 21 ha of agricultural patches (less than $1 \%$ of the total agricultural surface), with an individual patch extent ranging from 1.5 to 10.9 ha.

Moreover, plantation of biogeographically and ecologically coherent species is expected to aid native biodiversity and to guarantee cost-effectiveness and long-term persistence of the interventions [90-92].

\section{Discussion}

Prioritisation is recognised as a suitable tool for simultaneously and cost-effectively approach biodiversity and ES concerns at different levels [93]. Actually, it has been increasingly applied for GI design at broad levels, e.g., for the continental Europe [28,94] and at local level, especially for urban contexts $[95,96]$. On the contrary, despite the increasing interest in urban peripheries for experimenting sustainable land-use models, GI deployment is still infrequent in peri-urban settings [97] and respective prioritisation models are lacking.

In this respect, the main contribution of the present work is the development of a composite framework for guiding prioritisation throughout a peri-urban GI planning process, and its application to an agricultural sector in the metropolitan area of Rome.

First of all, the process deals with the definition of GI priority objectives, such as agriculture multifunctionality [98]; a priority location for GI deployment [99]; and the description of priority conservation and restoration actions [100]. Thus, it allows the reliability of a systematic and hierarchical arrangement of these different priorities to be made explicit and reinforced with respect to single purpose approaches [101]. Actually, the proposed arrangement satisfies the multi-scale perspective advocated for GI planning [102,103] by demonstrating the viability of (a) defining priority objectives at relatively broad landscape scale, corresponding to the metropolitan/regional decision level, (b) choosing priority spatial location at an intermediate countryside scale, corresponding to the municipal/sub-municipal decision level, and (c) outlining priority management actions at site scale, corresponding to the farm/field decision level.

Priorities for GI objectives were set at the landscape scale, which reflects the wide regional/metropolitan range at which land use and land take processes take place [104]. The collected information on ecosystem condition and pressures provided a systematic picture of which biodiversity targets should be primarily addressed in the eastern metropolitan sector of Rome. Concurrently, the analysis of the available documentation on environmental risks, sustainable agriculture targets and sustainable landscape development policies suggested which bundle of ES and therefore, which aspects of agriculture multifunctionality [34,59], should be first enhanced through ecosystem conservation and restoration in the overall sector. At this decision level, the case study provides concrete evidences for promoting the claimed integration of both biodiversity and ES targets into land planning $[105,106]$. Especially, it represents an example of how applying the GI approach in a peri-urban agricultural context can reinforce convergences among metropolitan sectoral plans for urban and rural development (e.g., the Provincial General Masterplan and the Regional Rural Development Plan), nature conservation (e.g., the Provincial Territorial Ecological Network) and water protection (e.g., the Regional Water Conservation Plan).

The selection of a priority location for the GI deployment was performed at the countryside scale, which allows to properly exemplify the critical values that biodiversity, ecological connectivity and water quality may concurrently reach in the urban-rural interface. At this level, regulatory responses are provided by the ecological networks of municipal plans, protected areas management plans and river basin sub-plans.

By means of the site selection phase that was carried out in the present case study, some practical evidences about the pivotal role of a GI planning process in promoting the sustainable and synergic 
implementation of these local plans along the urban-rural gradient, can be highlighted. First of all, the documentation regarding how much the condition of species, ecosystems and physical environment has been impaired by urban sprawl may give priority to the application of municipal ecological network measures in the site, speed up the actual institution of the agricultural and river corridor parks, and trigger the preservation of traditional and sustainable agricultural practices for addressing the rules of the Aniene River management plan. Secondly, the gap in alternative designated protected areas allowed to emphasise the crucial role of Natura2000 sites in preserving valuable habitats and species in such a peri-urban agricultural area [107]. Thirdly, under a multi-functional perspective for GI planning along urban-rural gradients [108], the inclusion of a stretch of the river with a moderate/poor ecological status triggered the definition of the synergic restoration measures for natural, agricultural and riparian ecosystems, which have been subsequently localised and prioritised with the final step of the GI design process. Nevertheless, owing to the main theoretical interest of this research, GI location has been top-down oriented. For an effective GI implementation, the opinion of stakeholders, above all farmers, land-owners and resident population should be mainstreamed into the decision process $[109,110]$. The limited extent of the site represents another potential shortcoming because it prevents the introduction of wider natural ecosystem patches under a 'land sparing' perspective [111,112]. Only 'land sharing' actions have been subsequently planned, i.e., creation and restoration of marginal vegetation elements. Yet, since these elements represent a very small part of the agricultural surface, potential conflicts with productive activities may be avoided.

At the farm/field scale, i.e., the level at which GI components and specific actions have been finally prioritised, the considered land sharing options address the establishment of Ecological Focus Areas (EFAs), as defined by the current EU agricultural policy. The planned EFAs (i.e., field margins, riparian corridors and small patches of non-farmed habitats) are altogether able to benefit biodiversity and provide the targeted bundle of ES [113-116]. These features necessarily need a prioritisation procedure based on fine-grained background information, at a similar scale of those conducted for planning strictly urban GI, e.g., for cooling or ameliorating air quality [32,117]. Apart from basic maps with a high spatial resolution, a combination of in-depth knowledge of vegetation potential, composition of native communities and biology of native species is necessary for the proper design of GI actions. This combination allows the effective foster of environmental benefits and the prevention of trade-offs between biodiversity conservation and ES provision $[75,118]$, also in a transitional peri-urban context.

\section{Conclusions}

Urban-rural interfaces offer an ideal ground for testing nature-based approaches aimed at the reduction of negative environmental impacts due to urban growth and, concurrently, at the valorisation of multifunctionality of peri-urban agroecosystems. GI, which is widely recognised as a win-win solution for people and nature, could provide a valuable mean to address these challenges. Nevertheless, in addition to synergies, trade-offs and/or unsustainable costs may arise from GI planning and implementation.

This study focuses on the role of prioritisation to avoid these potential drawbacks and, in this respect, contributes to the increasing number of examples of good practices. Beyond the evidences concerning the GI planning in a metropolitan area of the Mediterranean region, which is widely affected by the fragmentation and simplification of peri-urban landscapes, some general principles for priority setting in these systems have been either reinforced or originally developed.

Actually, the proposed multi-step and multi-scale framework (i) supports GI multifunctionality, by means of prioritisation of multiple objectives according to main demand for biodiversity and ES and in compliance with wide-area land planning tools; (ii) promotes the valorisation of traditional agricultural landscapes, by means of prioritisation of GI location according to co-occurring critical conditions and pressures on agroecosystems and in compliance with local development and management plans; and (iii) fosters the implementation of sustainable agricultural practices, by means of prioritisation of restoration and conservation actions according to the combined capacity of planned GI components to 
benefit biodiversity and provide the desired ES and in compliance with conditionality measures of the current EU agricultural policy.

Novel hints of the approach reside in the modulation of priority actions according to the urban-rural gradient and in the adoption of vegetation knowledge as basic ground through all the planning and prioritisation phases. Especially, this knowledge aided the definition of occurring ecosystems, the assessment of species and ecosystem conservation status, the definition of GI components and the selection of species to be primarily adopted for restoration actions. The last point ensures critical features of natural biodiversity, coherence with the potential natural vegetation, and functional relevance to be concurrently addressed by means of a cost-effective and long-term persistent GI interventions.

Finally, main limitations of the work, which will be addressed in the near future, are related to the top-down approach adopted throughout the planning process, to the lack of comprehensive analyses of the potential disservices provided by land-sharing interventions, and to the assessment of GI benefits that overlooks a more exhaustive definition of monetary and social values.

Author Contributions: Conceptualisation, G.C.; Methodology, G.C. and M.A.O.; Software, M.A.O. and V.D.L.; Validation, V.D.L.; Investigation, V.D.L.; Resources, G.C.; Writing-Original draft preparation, G.C., V.D.L. and M.A.O.; Writing-Review and editing, G.C. and M.A.O.; Supervision, G.C.; Funding acquisition, G.C.

Funding: This research was funded by Sapienza University of Rome (University Project 2017, prot. RP11715C7E59ADAA).

Acknowledgments: The authors wish to thank Laura Zavattero, for the support in collecting information at the metropolitan level.

Conflicts of Interest: The authors declare no conflict of interest. The funders had no role in the design of the study; in the collection, analyses, or interpretation of data; in the writing of the manuscript, or in the decision to publish the results.

\section{References}

1. Seto, K.C.; Fragkias, M.; Güneralp, B.; Reilly, M.K. A meta-analysis of global urban land expansion. PLoS ONE 2011, 6, e23777. [CrossRef]

2. Tilman, D.; Balzer, C.; Hill, J.; Befort, B.L. Global food demand and the sustainable intensification of agriculture. Proc. Natl. Acad. Sci. USA 2011, 108, 20260-20264. [CrossRef] [PubMed]

3. Iojă, C.I.; Niţă, M.R.; Vânău, G.O.; Onose, D.A.; Gavrilidis, A.A. Using multi-criteria analysis for the identification of spatial land-use conflicts in the Bucharest Metropolitan Area. Ecol. Indic. 2014, 42, 112-121. [CrossRef]

4. Marraccini, E.; Debolini, M.; Moulery, M.; Abrantes, P.; Bouchier, A.; Chéry, J.P.; Sanz Sanz, E.; Sabbatini, T.; Napoleone, C. Common features and different trajectories of land cover changes in six Western Mediterranean urban regions. Appl. Geogr. 2015, 62, 347-356. [CrossRef]

5. Salvati, L.; Mavrakis, A. Narrative and quantitative analysis of human pressure, land-use and climate aridity in a transforming industrial basin in Greece. Int. J. Environ. Res. 2014, 8, 115-122.

6. Vizzari, M.; Sigura, M. Landscape sequences along the urban-rural-natural gradient: A novel geospatial approach for identification and analysis. Landsc. Urban Plan. 2015, 140, 42-55. [CrossRef]

7. Vizzari, M.; Hilal, M.; Sigura, M.; Antognelli, S.; Joly, D. Urban-rural-natural gradient analysis with CORINE data: An application to the metropolitan France. Landsc. Urban Plan. 2018, 171, 18-29. [CrossRef]

8. Allen, A. Environmental planning and management of the peri-urban interface: Perspectives on an emerging field. Environ. Urban 2003, 15, 135-148. [CrossRef]

9. Herrero-Jáuregui, C.; Arnaiz-Schmitz, C.; Reyes, M.; Telesnicki, M.; Agramonte, I.; Easdale, M.; Schmitz, M.F.; Aguiar, M.; Gómez-Sal, A.; Montes, C. What do We Talk about When We Talk about Social-Ecological Systems? A Literature Review. Sustainability 2018, 10, 2950. [CrossRef]

10. Kroll, F.; Müller, F.; Haase, D.; Fohrer, N. Rural-urban gradient analysis of ecosystem services supply and demand dynamics. Land Use Policy 2012, 29, 521-535. [CrossRef]

11. Tu, M.C.; Smith, P. Modeling Pollutant Buildup and Washoff Parameters for SWMM Based on Land Use in a Semiarid Urban Watershed. Water Air Soil Pollut. 2018, 229, 121. [CrossRef] 
12. Alberti, M. The Effects of Urban Patterns on Ecosystem Function. Int. Reg. Sci. Rev. 2005, 28, 168-192. [CrossRef]

13. Bajocco, S.; De Angelis, A.; Perini, L.; Ferrara, A.; Salvati, L. The Impact of Land Use/Land Cover Changes on Land Degradation Dynamics: A Mediterranean Case Study. Environ. Manag. 2012, 49, 980. [CrossRef] [PubMed]

14. EC (European Commission). Communication from the Commission to the European Parliament, the Council, the European Economic and Social Committee and the Committee of the Regions 'Green Infrastructure (GI)_Enhancing Europe's Natural Capital' (COM(2013) 249 Final of 6 May 2013). 2013. Available online: http://eur-lex.europa.eu/LexUriServ/LexUriServ.do?uri=COM:2013:0249:FIN:EN:PDF (accessed on 18 March 2019).

15. Lafortezza, R.; Davies, C.; Sanesi, G.; Konijnendijk, C.C. Green Infrastructure as a tool to support spatial planning in European urban regions. iForest 2013, 6, 102. [CrossRef]

16. O’Brien, L.; De Vreese, R.; Kern, M.; Sievänen, T.; Stojanova, B.; Atmiş, E. Cultural ecosystem benefits of urban and peri-urban green infrastructure across different European countries. Urban For. Urban Green. 2017, 24, 236-248. [CrossRef]

17. Sanesi, G.; Colangelo, G.; Lafortezza, R.; Calvo, E.; Davies, C. Urban green infrastructure and urban forests: A case study of the Metropolitan Area of Milan. Landsc. Res. 2017, 42, 164-175. [CrossRef]

18. Lennon, M. Green infrastructure and planning policy: A critical assessment. Local Environ. 2015, 20, 957-980. [CrossRef]

19. Schneiders, A.; Van Daele, T.; Van Landuyt, W.; Van Reeth, W. Biodiversity and ecosystem services: Complementary approaches for ecosystem management? Ecol. Indic. 2012, 21, 123-133. [CrossRef]

20. Baró, F.; Gómez-Baggethun, E.; Haase, D. Ecosystem service bundles along the urban-rural gradient: Insights for landscape planning and management. Ecosyst. Serv. 2017, 24, 147-159. [CrossRef]

21. EC (European Commission). Communication from the Commission to the European Parliament, the Council, the Economic and Social Committee and the Committee of the Regions. Our life Insurance, Our Natural Capital: An EU Biodiversity Strategy to 2020 (COM(2011)244 Final). 2011. Available online: http://eur-lex.europa.eu/legal-content/EN/TXT/?uri=celex\%3A52011DC0244 (accessed on 18 March 2019).

22. EC (European Commission). Key European Action Supporting the 2030 Agenda and the Sustainable Development Goals (COM(2016) 739 Final). 2016. Available online: https://ec.europa.eu/europeaid/sites/ devco/files/swd-key-european-actions-2030-agenda-sdgs-390-20161122_en.pdf (accessed on 18 March 2019).

23. Salbitano, F.; Borelli, S.; Conigliaro, M.; Yujuan, C. Guidelines on Urban and Peri-Urban Forestry; FAO Forestry Paper No. 178; Food and Agriculture Organization of the United Nations: Rome, Italy, 2016.

24. Wendling, L.A.; Huovila, A.; zu Castell-Rüdenhausen, M.; Hukkalainen, M.; Airaksinen, M. Benchmarking Nature-Based Solution and Smart City assessment schemes against the Sustainable Development Goal indicator framework. Front. Environ. Sci. 2018, 6, 69. [CrossRef]

25. Baró, F.; Palomo, I.; Zulian, G.; Vizcaino, P.; Haase, D.; Gómez-Baggethun, E. Mapping ecosystem service capacity, flow and demand for landscape and urban planning: A case study in the Barcelona metropolitan region. Land Use Policy 2016, 57, 405-417. [CrossRef]

26. Larondelle, N.; Haase, D. Urban ecosystem services assessment along a rural-urban gradient: A cross-analysis of European cities. Ecol. Indic. 2013, 29, 179-190. [CrossRef]

27. Maes, J.; Teller, A.; Erhard, M.; Grizzetti, B.; Barredo, J.I.; Paracchini, M.-L.; Condé, S.; Somma, F.; Orgiazzi, A.; Jones, A.; et al. Mapping and Assessment of Ecosystems and Their Services: An Analytical Framework for Ecosystem Condition; Publications office of the European Union: Luxembourg, 2018.

28. Vallecillo, S.; Polce, C.; Barbosa, A.; Castillo, C.P.; Vandecasteele, I.; Rusch, G.M.; Maes, J. Spatial alternatives for Green Infrastructure planning across the EU: An ecosystem service perspective. Landsc. Urban Plan. 2018, 174, 41-54. [CrossRef]

29. Garmendia, E.; Apostolopoulou, E.; Adams, W.M.; Bormpoudakis, D. Biodiversity and green infrastructure in Europe: Boundary object or ecological trap? Land Use Policy 2016, 56, 315-319. [CrossRef]

30. Pelorosso, R.; Gobattoni, F.; Geri, F.; Leone, A. PANDORA 3.0 plugin: A new biodiversity ecosystem service assessment tool for urban green infrastructure connectivity planning. Ecosyst. Serv. 2017, 26, 476-482. [CrossRef]

31. EEA (European Environment Agency). Spatial Analysis of Green Infrastructure in Europe Technical Report No 2/2014; Publications Office of the European Union: Luxembourg, 2014. 
32. Kukkala, A.S.; Moilanen, A. Ecosystem services and connectivity in spatial conservation prioritization. Landsc. Ecol. 2016, 32, 5-14. [CrossRef]

33. Jacobs, S.; Verheyden, W.; Dendoncker, N. Why to map? In Mapping Ecosystem Services; Burkhard, B., Maes, J., Eds.; Pensoft Publishers: Sofia, Bulgaria, 2017.

34. Verhagen, W.; Kukkala, A.S.; Moilanen, A.; van Teeffelen, A.J.; Verburg, P.H. Use of demand for and spatial flow of ecosystem services to identify priority areas. Conserv. Biol. 2017, 31, 860-871. [CrossRef] [PubMed]

35. Kremer, P.; Hamstead, Z.A.; McPhearson, T. The value of urban ecosystem services in New York City: A spatially explicit multicriteria analysis of landscape scale valuation scenarios. Environ. Sci. Policy 2016, 62, 57-68. [CrossRef]

36. Norton, B.A.; Coutts, A.M.; Livesley, S.J.; Harris, R.J.; Hunter, A.M.; Williams, N.S. Planning for cooler cities: A framework to prioritise green infrastructure to mitigate high temperatures in urban landscapes. Landsc. Urban Plan. 2015, 134, 127-138. [CrossRef]

37. Derkzen, M.L.; van Teeffelen, A.J.A.; Verburg, P.H. Green infrastructure for urban climate adaptation: How do residents' views on climate impacts and green infrastructure shape adaptation preferences? Landsc. Urban Plan. 2017, 157, 106-130. [CrossRef]

38. Hansen, R.; Pauleit, S. From multifunctionality to multiple ecosystem services? A conceptual framework for multifunctionality in green infrastructure planning for urban areas. Ambio 2014, 43, 516-529. [CrossRef]

39. Albert, C.; Von Haaren, C. Implications of Applying the Green Infrastructure Concept in Landscape Planning for Ecosystem Services in Peri-Urban Areas: An Expert Survey and Case Study. Plan. Pract. Res. 2017, 32, 227-242. [CrossRef]

40. Estreguil, C.; Caudullo, G.; Rega, C.; Paracchini, M.L. Enhancing Connectivity, Improving Green Infrastructure. Cost-Benefit Solutions for Forest and Agri-Environment; A Pilot Study in Lombardy; Office for Official Publications of the European Union: Luxembourg, 2016.

41. Spanò, M.; Gentile, F.; Davies, C.; Lafortezza, R. The DPSIR framework in support of green infrastructure planning: A case study in Southern Italy. Land Use Policy 2017, 61, 242-250. [CrossRef]

42. Blasi, C.; Capotorti, G.; Marchese, M.; Marta, M.; Bologna, M.A.; Bombi, P.; Bonaiuto, M.; Bonnes, M.; Carrus, G.; Cifelli, F.; et al. Interdisciplinary research for the proposal of the Urban Biosphere Reserve of Rome Municipality. Plant Biosyst. 2008, 142, 305-312. [CrossRef]

43. Blasi, C.; Capotorti, G.; Copiz, R.; Guida, D.; Mollo, B.; Smiraglia, D.; Zavattero, L. Classification and mapping of the ecoregions of Italy. Plant Biosyst. 2014, 148, 1255-1345. [CrossRef]

44. Salvati, L. Agro-forest landscape and the 'fringe' city: A multivariate assessment of land-use changes in a sprawling region and implications for planning. Sci. Total Environ. 2014, 490, 715-723. [CrossRef]

45. Salvati, L.; Sabbi, A. Exploring long-term land cover changes in an urban region of southern Europe. Int. J. Sustain. Dev. World Ecol. 2011, 18, 273-282. [CrossRef]

46. Frondoni, R.; Mollo, B.; Capotorti, G. A landscape analysis of land cover change in the Municipality of Rome (Italy): Spatio-temporal characteristics and ecological implications of land cover transitions from 1954 to 2001. Landsc. Urban Plan. 2011, 100, 117-128. [CrossRef]

47. Regione Lazio. Regional Statistics: Resident Population, Territorial Surface, Density and Mountain Municipalities at 1 January 2013. 2013. Available online: http://www.regione.lazio.it/statistica/areeTematiche/ elenco/0/11/0/ (accessed on 18 March 2019).

48. Capotorti, G.; Alós Ortí, M.M.; Copiz, R.; Fusaro, L.; Mollo, B.; Salvatori, E.; Zavattero, L. Biodiversity and ecosystem services in urban green infrastructure planning: A case study from the metropolitan area of Rome (Italy). Urban For. Urban Green. 2019, 37, 87-96. [CrossRef]

49. Blasi, C.; Zavattero, L.; Marignani, M.; Smiraglia, D.; Copiz, R.; Rosati, L.; Del Vico, E. The concept of land ecological network and its design using a land unit approach. Plant Biosyst. 2008, 142, 540-549. [CrossRef]

50. CIRBFEP (Centro di Ricerca Interuniversitario Biodiversità, Fitosociologia ed Ecologia del Paesaggio). Relazione Finale su Serie di Vegetazione e Vegetazione Naturale Potenziale della Provincia di Roma. 2013. Available online: http://websit.cittametropolitanaroma.gov.it/BDV2014/RelazioneP.pdf (accessed on 18 March 2019).

51. CIRBFEP (Centro di Ricerca Interuniversitario Biodiversità, Fitosociologia ed Ecologia del Paesaggio). Carta della Vegetazione reale della Provincia di Roma. 2013. Available online: http://websit.cittametropolitanaroma. gov.it/BDV2014/100_vr_ridotta_4nov.jpg (accessed on 18 March 2019). 
52. Provincia di Roma. PTPG: Rapporto Territorio. 2010. Available online: http://ptpg.cittametropolitanaroma. gov.it/UploadDocs/2010/rapporto_territorio/ (accessed on 18 March 2019).

53. Regione Lazio. Parchi e Natura 2000. 2011. Available online: http://www.regione.lazio.it/prl_ambiente/?vw= contenutidettaglio\&id=202 (accessed on 18 March 2019).

54. Cavallo, A.; Di Donato, B.; Marino, D. Mapping and assessing urban agriculture in Rome. Agric. Agric. Sci. Procedia 2016, 8, 774-783. [CrossRef]

55. Salvati, L.; Munafò, M.; Morelli, V.G.; Sabbi, A. Low-density settlements and land use changes in a Mediterranean urban region. Landsc. Urban Plan. 2012, 105, 43-52. [CrossRef]

56. Regione Lazio. Piano di tutela delle acque regionale (PTAR) Aggiornamento. 2016. Available online: http://www.regione.lazio.it/prl_ambiente/?vw=documentazioneDettaglio\&id=39549 (accessed on 18 March 2019).

57. Berry, P.; Turkelboom, F.; Verheyden, W.; Martín-López, B. Ecosystem Services Bundles. In Ecosystem Services Reference Book; Potschin, M., Jax, K., Eds.; 2016; Available online: www.openness-project.eu/library/referencebook (accessed on 18 March 2019).

58. Raudsepp-Hearne, C.; Peterson, G.D.; Bennett, E.M. Ecosystem service bundles for analyzing tradeoffs in diverse landscapes. Proc. Natl. Acad. Sci. USA 2010, 107, 5242-5247. [CrossRef]

59. Huang, J.; Tichit, M.; Poulot, M.; Darly, S.; Li, S.; Petit, C.; Aubry, C. Comparative review of multifunctionality and ecosystem services in sustainable agriculture. J. Environ. Manag. 2015, 149, 138-147. [CrossRef]

60. Maes, J.; Liquete, C.; Teller, A.; Erhard, M.; Paracchini, M.L.; Barredo, J.I.; Grizzetti, B.; Cardoso, A.; Somma, F.; Petersen, J.-E.; et al. An indicator framework for assessing ecosystem services in support of the EU Biodiversity Strategy to 2020. Ecosyst. Serv. 2016, 17, 14-23. [CrossRef]

61. Power, A.G. Ecosystem services and agriculture: Tradeoffs and synergies. Philos. Trans. R. Soc. Lond. B Biol. Sci. 2010, 365, 2959-2971. [CrossRef]

62. Wiggering, H.; Weißhuhn, P.; Burkhard, B. Agrosystem Services: An Additional Terminology to Better Understand Ecosystem Services Delivered by Agriculture. Landsc. Online 2016, 49, 1-15. [CrossRef]

63. Hahs, A.K.; McDonnell, M.J. Selecting independent measures to quantify Melbourne's urban-rural gradient. Landsc. Urban Plan. 2006, 78, 435-448. [CrossRef]

64. Newbold, T.; Hudson, L.N.; Hill, S.L.; Contu, S.; Lysenko, I.; Senior, R.A.; Day, J. Global effects of land use on local terrestrial biodiversity. Nature 2015, 520, 45-50. [CrossRef]

65. Regione Lazio. Carta delle formazioni naturali e seminaturali della Regione Lazio mediante approfondimento a IV e V livello Corine Land Cover della Carta dell’Uso del Suolo della Regione Lazio. 2011. Available online: http://dati.lazio.it/catalog/it/dataset/cus-lazio-approfondimento-delle-formazioni-naturalie-seminaturali-iv-e-v-livello-corine-land-cover (accessed on 18 March 2019).

66. Blasi, C.; Capotorti, G.; Alós Ortí, M.M.; Anzellotti, I.; Attorre, F.; Azzella, M.M.; Carli, E.; Copiz, R.; Garfi, V.; Manes, F.; et al. Ecosystem mapping for the implementation of the European Biodiversity Strategy at the national level: The case of Italy. Environ. Sci. Policy 2017, 78, 173-184. [CrossRef]

67. Maes, J.; Teller, A.; Erhard, M.; Liquete, C.; Braat, L.; Berry, P.; Egoh, B.; Puydarrieux, P.; Fiorina, C.; Santos, F.; et al. Mapping and Assessment of Ecosystems and Their Services. An Analytical Framework for Ecosystem Assessments Under Action 5 of the EU Biodiversity Strategy to 2020; Publications Office of the European Union: Luxembourg, 2013.

68. Arnaiz-Schmitz, C.; Herrero-Jáuregui, C.; Schmitz, M.F. Losing a heritage hedgerow landscape. Biocultural diversity conservation in a changing social-ecological Mediterranean system. Sci. Total Environ. 2018, 637, 374-384. [CrossRef]

69. García-Feced, C.; Weissteiner, C.J.; Baraldi, A.; Paracchini, M.L.; Maes, J.; Zulian, G.; Kempen, M.; Elbersen, B.; Pérez-Soba, M. Semi-natural vegetation in agricultural land: European map and links to ecosystem service supply. Agron. Sustain. Dev. 2015, 35, 273-283. [CrossRef]

70. Capotorti, G.; Alós Ortí, M.M.; Anzellotti, I.; Azzella, M.M.; Copiz, R.; Mollo, B.; Zavattero, L. The MAES process in Italy: Contribution of vegetation science to implementation of European Biodiversity Strategy to 2020. Plant Biosyst. 2015, 149, 949-953. [CrossRef]

71. Capotorti, G.; Zavattero, L.; Anzellotti, I.; Burrascano, S.; Frondoni, R.; Marchetti, M.; Marignani, M.; Smiraglia, D.; Blasi, C. Do National Parks play an active role in conserving the natural capital of Italy? Plant Biosyst. 2012, 146, 258-265. [CrossRef] 
72. Capotorti, G.; Mollo, B.; Zavattero, L.; Anzellotti, I.; Celesti-Grapow, L. Setting priorities for urban forest planning. A comprehensive response to ecological and social needs for the metropolitan area of Rome (Italy). Sustainability 2015, 7, 3958-3976. [CrossRef]

73. McGarigal, K.; Cushman, S.A.; Neel, M.C.; Ene, E. Fragstats: Spatial Pattern Analysis Program for Categorical Maps. Available online: http://www.umass.edu/landeco/research/fragstats/fragstats.html (accessed on 18 March 2019).

74. Capotorti, G.; Del Vico, E.; Lattanzi, E.; Tilia, A.; Celesti-Grapow, L. Exploring biodiversity in a metropolitan area in the Mediterranean region: The urban and suburban flora of Rome (Italy). Plant Biosyst. 2013, 147, 174-185. [CrossRef]

75. Capotorti, G.; Del Vico, E.; Anzellotti, I.; Celesti-Grapow, L. Combining the conservation of biodiversity with the provision of ecosystem services in urban green infrastructure planning: Critical features arising from a case study in the metropolitan area of Rome. Sustainability 2017, 9, 10. [CrossRef]

76. Comitato del Verde Pubblico (Italian Public Green Committee). Strategia Nazionale del Verde Urbano. 2018. Available online: http://www.minambiente.it/sites/default/files/archivio/allegati/comitato\%20verde\% 20pubblico/strategia_verde_urbano.pdf (accessed on 18 March 2019).

77. Aparicio, A.; Albaladejo, R.G.; Olalla-Tárraga, M.A.; Carrillo, L.F.; Rodríguez, M.Á. Dispersal potentials determine responses of woody plant species richness to environmental factors in fragmented Mediterranean landscapes. For. Ecol. Manag. 2008, 255, 2894-2906. [CrossRef]

78. Flynn, S.; Turner, R.M.; Stuppy, W.H. Seed Information Database. 2006. Available online: http://www.kew. org/data/sid (accessed on 18 March 2019).

79. Mirabile, M.; Bianco, P.M.; Silli, V.; Brini, S.; Chiesura, A.; Vitullo, M.; Ciccarese, L.; De Lauretis, R.; Gaudioso, D. Guidelines of Sustainable Urban Forestry for the Municipality of Rome; ISPRA: Roma, Italy, 2015.

80. Mazzone, P.; Persano Oddo, L. Apicoltura e Mieli Della Campania; Campania Region Department of Agriculture: Naples, Italy, 2003.

81. Persano Oddo, L. Mieli e flora mellifera del Lazio; Regione Lazio: Rete Rurale Nazionale, Italy, 2006.

82. Salvati, L. Lost in complexity, found in dispersion: 'Peripheral'development and deregulated urban growth in Rome. Cities 2015, 47, 73-80. [CrossRef]

83. Borrelli, P. Studio del rischio di erosione del suolo nelle aree agricole della provincia di Roma: Valutazioni preliminari alla luce dei recenti eventi meteorologici di straordinaria intensità. In L'analisi Del Rischio Ambientale. La Lettura Del Geografo; Di Somma, A., Ferrari, V., Eds.; Associazione Geografica per l'Ambiente e il Territorio-AGAT: Roma, Italy, 2012.

84. Manfreda, S.; Nardi, F.; Samela, C.; Grimaldi, S.; Taramasso, A.C.; Roth, G.; Sole, A. Investigation on the use of geomorphic approaches for the delineation of flood prone areas. J. Hydrol. 2014, 517, 863-876. [CrossRef]

85. Piazza, M.G. Mappatura Delle Aree Nettarifere Del Lazio; CRA, Istituto Sperimentale di Zoologia Agraria, Sezione Apicoltura: Roma, Italy, 2007.

86. De Natale, F.; Pignatti, G.; Trisorio, A. Aree Agricole Ad Alto Valore Naturale; Regione Lazio: Rete Rurale Nazionale, Italy, 2014; Available online: https://www.reterurale.it/flex/cm/pages/ServeBLOB.php/L/IT/ IDPagina/13563 (accessed on 18 March 2019).

87. Henke, R.; Vanni, F. Il carattere periurbano dell'agricoltura romana. Roma Mod. E Contemp. 2016, 24, 77-106. [CrossRef]

88. Giardini, M. La flora vascolare del Montarozzo del Barco. Ann. Mus. Civ. Rovereto 2013, 28, 161-197.

89. Anzalone, B.; Iberite, M.; Lattanzi, E. La Flora vascolare del Lazio. Inf. Bot. Ital. 2010, 42, 187-317.

90. Bakker, J.D.; Wilson, S.D. Using ecological restoration to constrain biological invasion. J. Appl. Ecol. 2004, 41, 1058-1064. [CrossRef]

91. Bullock, J.M.; Aronson, J.; Newton, A.C.; Pywell, R.F.; Rey-Benayas, J.M. Restoration of ecosystem services and biodiversity: Conflicts and opportunities. Trends Ecol. Evol. 2011, 26, 541-549. [CrossRef]

92. Harvey, C.A.; Komar, O.; Chazdon, R.; Ferguson, B.G.; Finegan, B.; Griffith, D.M.; Martínez-Ramos, M.; Morales, H.; Nigh, R.; Soto-Pinto, L.; et al. Integrating agricultural landscapes with biodiversity conservation in the Mesoamerican hotspot. Conserv. Biol. 2008, 22, 8-15. [CrossRef]

93. Snäll, T.; Lehtomäki, J.; Arponen, A.; Elith, J.; Moilanen, A. Green infrastructure design based on spatial conservation prioritization and modeling of biodiversity features and ecosystem services. Environ. Manag. 2016, 57, 251-256. [CrossRef] 
94. Liquete, C.; Kleeschulte, S.; Dige, G.; Maes, J.; Grizzetti, B.; Olah, B.; Zulian, G. Mapping green infrastructure based on ecosystem services and ecological networks: A pan-European case study. Environ. Sci. Policy 2015, 54, 268-280. [CrossRef]

95. Meerow, S.; Newell, J.P. Spatial planning for multifunctional green infrastructure: Growing resilience in Detroit. Landsc. Urban Plan. 2017, 159, 62-75. [CrossRef]

96. Madureira, H.; Andresen, T. Planning for multifunctional urban green infrastructures: Promises and challenges. Urban Des. Int. 2014, 19, 38-49. [CrossRef]

97. Geneletti, D.; La Rosa, D.; Spyra, M.; Cortinovis, C. A review of approaches and challenges for sustainable planning in urban peripheries. Landsc. Urban Plan. 2017, 165, 231-243. [CrossRef]

98. Rolf, W.; Peters, D.; Lenz, R.; Pauleit, S. Farmland-an Elephant in the Room of Urban Green Infrastructure? Lessons learned from connectivity analysis in three German cities. Ecol. Indic. 2018, 94, 151-163. [CrossRef]

99. Niedźwiecka-Filipiak, I.; Rubaszek, J.; Potyrała, J.; Filipiak, P. The Method of Planning Green Infrastructure System with the Use of Landscape-Functional Units (Method LaFU) and its Implementation in the Wrocław Functional Area (Poland). Sustainability 2019, 11, 394. [CrossRef]

100. Dondina, O.; Saura, S.; Bani, L.; Mateo-Sánchez, M.C. Enhancing connectivity in agroecosystems: Focus on the best existing corridors or on new pathways? Landsc. Ecol. 2018, 33, 1741-1756. [CrossRef]

101. Estreguil, C.; Dige, G.; Kleeschulte, S.; Carrao, H.; Raynal, J.; Teller, A. Informing Strategic Green Infrastructure and Restoration Planning Through Mapping and Assessment Methods Based on Spatial and Technical Data. European Commission. 2018. Available online: https://www.eustafor.eu/uploads/ReportGI_ EUSTAFORcomments.pdf (accessed on 18 March 2019).

102. Lammerant, J.; Peters, R.; Snethlage, M.; Delbaere, B.; Dickie, I.; Whiteley, G. Implementation of 2020 EU Biodiversity Strategy: Priorities for the Restoration of Ecosystems and Their Services in the EU; Report to the European Commission; Arcadis: Amsterdam, The Netherlands, 2013.

103. Rodríguez-Loinaz, G.; Alday, J.G.; Onaindia, M. Multiple ecosystem services landscape index: A tool for multifunctional landscapes conservation. J. Environ. Manag. 2014, 147C, 152-163. [CrossRef]

104. Lefebvre, M.; Espinosa, M.; Gomez y Paloma, S.; Paracchini, M.L.; Piorr, A.; Zasada, I. Agricultural landscapes as multi-scale public good and the role of the Common Agricultural Policy. J. Environ. Plan. Manag. 2015, 58, 2088-2112. [CrossRef]

105. Grêt-Regamey, A.; Weibel, B.; Rabe, S.E.; Burkhard, B. A tiered approach for ecosystem services mapping. In Mapping Ecosystem Services; Burkhard, B., Maes, J., Eds.; Pensoft Publishers: Sofia, Bulgaria, 2017; pp. $213-217$.

106. Lennon, M.; Scott, M. Delivering ecosystems services via spatial planning: Reviewing the possibilities and implications of a green infrastructure approach. Town Plan. Rev. 2014, 85, 563-587. [CrossRef]

107. Ustaoglu, E.; Williams, B. Determinants of Urban Expansion and Agricultural Land Conversion in 25 EU Countries. Environ. Manag. 2017, 60,717-746. [CrossRef]

108. Balzan, M.V.; Caruana, J.; Zammit, A. Assessing the capacity and flow of ecosystem services in multifunctional landscapes: Evidence of a rural-urban gradient in a Mediterranean small island state. Land Use Policy 2018, 75, 711-725. [CrossRef]

109. Hauck, J.; Schmidt, J.; Werner, A. Using social network analysis to identify key stakeholders in agricultural biodiversity governance and related land-use decisions at regional and local level. Ecol. Soc. 2016, 21, 49. [CrossRef]

110. Zhang, W.; Ricketts, T.H.; Kremen, C.; Carney, K.; Swinton, S.M. Ecosystem services and dis-services to agriculture. Ecol. Econ. 2007, 64, 253-260. [CrossRef]

111. Benayas, J.M.R.; Bullock, J.M. Vegetation restoration and other actions to enhance wildlife in European agricultural landscapes. In Rewilding European Landscapes; Pereira, H.M., Navarro, L., Eds.; Springer: Cham, Switzerland, 2015; pp. 127-142.

112. Barral, M.P.; Benayas, J.M.R.; Meli, P.; Maceira, N.O. Quantifying the impacts of ecological restoration on biodiversity and ecosystem services in agroecosystems: A global meta-analysis. Agric. Ecosyst. Environ. 2015, 202, 223-231. [CrossRef]

113. de la Fuente, B.; Mateo-Sánchez, M.C.; Rodríguez, G.; Gastón, A.; de Ayala, R.P.; Colomina-Pérez, D.; Melero, M.; Saura, S. Natura 2000 sites, public forests and riparian corridors: The connectivity backbone of forest green infrastructure. Land Use Policy 2018, 75, 429-441. [CrossRef]

114. Fanfarillo, E.; Latini, M.; Bonifazi, E.; Nescatelli, S.; Abbate, G. Evaluating and mapping naturalness of agricultural areas: A case study in central Italy. Plant Biosyst. 2017, 151, 766-769. [CrossRef] 
115. Howe, C.; Suich, H.; Vira, B.; Mace, G.M. Creating win-wins from trade-offs? Ecosystem services for human well-being: A meta-analysis of ecosystem service trade-offs and synergies in the real world. Glob. Environ. Chang. 2014, 28, 263-275. [CrossRef]

116. Morelli, F.; Pruscini, F.; Santolini, R.; Perna, P.; Benedetti, Y.; Sisti, D. Landscape heterogeneity metrics as indicators of bird diversity: Determining the optimal spatial scales in different landscapes. Ecol. Indic. 2013, 34, 372-379. [CrossRef]

117. Marando, F.; Salvatori, E.; Sebastiani, A.; Fusaro, L.; Manes, F. Regulating Ecosystem Services and Green Infrastructure: Assessment of Urban Heat Island effect mitigation in the municipality of Rome, Italy. Ecol. Model. 2019, 392, 92-102. [CrossRef]

118. Tomaselli, V.; Adamo, M.; Veronico, G.; Sciandrello, S.; Tarantino, C.; Dimopoulos, P.; Medagli, P.; Nagendra, H.; Blonda, P. Definition and application of expert knowledge on vegetation pattern, phenology, and seasonality for habitat mapping, as exemplified in a Mediterranean coastal site. Plant Biosyst. 2017, 151, 887-899. [CrossRef]

(C) 2019 by the authors. Licensee MDPI, Basel, Switzerland. This article is an open access article distributed under the terms and conditions of the Creative Commons Attribution (CC BY) license (http://creativecommons.org/licenses/by/4.0/). 